\title{
Energy Absorption Capacity Of Rat-Trap Bond Masonry Under Base Excitation
}

\author{
Eshetu Mathewos Juta \\ Assistant professor, Department of civil engineering, wolaita sodo University Ethiopia \\ Email id: eshetum90@gmail.com
}

\begin{abstract}
Brick masonry does not exhibit much capacity to resist lateral loads and hence the masonry suffers heavy damage during earthquakes, which impart lateral loads to structures. In the Bhuj earthquake of Jan 26, 2001, that occurred in majority of masonry structures failed because they were built with un-reinforced brick masonry. The EBC code of practice for brick masonry, suggests the use of lintel band and roof band that introduce a rigid box-type behavior which will help the structure to improve its performance against seismic loads. But there are no Codal provisions for use of Rat-Trap bond masonry which has been found to possess good seismic resistance characteristics. Rat-Trap bond system consists of an array of headers and stretchers with bricks laid vertically on the edge to form a cavity within a set of two headers and two stretchers. In this investigation, an attempt has been made to study the behavior of un-reinforced Rat-Trap bond masonry of two categories viz., (i) with roof slab, and (ii) without roof slab. Shock-table tests on one-third scale masonry building models ( with and without roof slabs ) were carried out to study the behavior. The peak accelerations were recorded for each shock. The scaled bricks were obtained by cutting locally available bricks using special tools. The size of the masonry models was $2 \mathrm{~m} \times 1 \mathrm{~m} \times 1 \mathrm{~m}$. The amount of energy imparted during each shock was measured before total collapse both for Rat-Trap bond masonry models with and without roof slabs. The results of the tests revealed that the roof weight plays an important role in the design of Rat-Trap masonry systems subject to seismic loads.
\end{abstract}

Key words: Rat-trap bond, scaled bricks, unreinforced masonry, Energy dissipation, Earthquake, Scaled Bricks

\section{INTRODUCTION}

A variety of masonry structures are constructed in Ethiopia using different types of blocks, bricks, stones etc. and different types of mortar such as mud mortar, lime mortar and cement mortar. Though the properties of the constituents of masonry are well known, the information regarding the dynamic behavior of masonry is scant. Masonry walls are known to suffer maximum damage during earthquakes. While such a masonry structure is subjected to lateral inertial loads during an earthquake, the walls develop shear and flexural stresses. The strength of masonry under these conditions often depends on the bond between brick and mortar. A masonry wall can also undergo in-plane shear stresses due to gravity loads in the plane of the wall. Shear failure in the form of diagonal cracks is observed due to this. The brittle nature of masonry leads to sudden and catastrophic collapse of walls when the wall experiences out of plane failure. A masonry building with openings and different types of roofing system is a complex structure and it is very difficult to understand and simulate the failure patterns of the building analytically, especially when it is subjected to ground induced lateral vibrations.

To understand the complex behaviour of masonry buildings during ground motion sophisticated facilities such as a shacking table with data acquisition systems with associated instrumentation are needed. However the test on a fullscale prototype is an expensive proposition, especially when parametric studies are to be carried out. In the context of the study of earthquake resistant features, test on small scale model become indispensable. Here tests are conducted on small scale models in order to obtain the response characteristics of a geometrically similar full scale prototype. The primary objective of the test was to develop a shock table and to study the base shock resistance and failure patterns of simple box type masonry-building models with and without roof slab. EBC code has defined a box type construction as consisting of masonry wall along both the axes of the building. The walls support vertical loads and also act as shear wall for horizontal loads acting in any direction. 


\section{LITERATURE REVIEW}

Jagadish et al. (2002) had fabricated a small rectangular shock table to test the behaviour of (1/6)th scale building models to base shock induced vibrations. The primary objective was to study the failure pattern of simple box type masonry building without any earthquake resistant feature particularly the out-of-plane (flexural) failure of the longer cross wall.

Deodhar and Patel (2008) worked on behaviour of brick masonry in compression. They studied different parameters like size of brick, role of frog, and mortar thickness on crushing strength of brick masonry. The conclusions are large brick size gives more strength and economy hence only metric bricks of size $200 \mathrm{~mm} \times 100 \mathrm{~mm} \times 100 \mathrm{~mm}$ should be used in practice. Rectangular frog gives higher strength. Frog is found to be more useful to increase load carrying capacity of masonry in flexure and shear. A joint thickness of $5 \mathrm{~mm}$ to $10 \mathrm{~mm}$ gives maximum strength. Higher mortar thickness reduces adhesion between brick and mortar and consequently reduces the strength of brick masonry.

Patil and Achawal (2000) worked on strength of brick masonry prisms using low strength bricks and cement mortar. This paper discusses the strength of bricks collected from different geographical location of Marathawada region of Maharashtra state of India. Brick strength ranges between 3 to $7 \mathrm{MPa}$. Water absorption of bricks is an independent parameter and does not depend on the compressive strength of bricks.

Thomas (2007), Compressive strength of brick masonry prisms by using brick samples from different regions of Marathwada were determined using cement mortars of various proportions. Increase in mortar strength and brick strength both lead to increased masonry strength according to but in neither case in direct proportion. It is more economical to increase brick strength rather than mortar strength for improving the masonry strength.

Borri et al. (2001) studied vaults and arches. According to the result obtained the use of FRP inhibits the out-ofplane mechanisms of masonry walls and permits the transfer of stresses to the wall parallel to the direction of seismic action and increase in ductility of the masonry structures.

Shrive (2004) GFRP applied on both sides of wall, the flexural strength of walls were increased up to 32 times self weight of wall. The deformation resisting capacity is 14 times that permitted.

\section{EXPERIMENTAL PROGRAMME}

Brick work building can be constructed without heavy capital expenditure. Laurie Baker is one of the minimal cost. In the conventional English bond wall, the major component of the cost is the material cost, i.e., the cost of bricks and mortar. Hence, to reduce the cost, some new technique should be adopted so as to reduce the brick as well as mortar works consumption. One of the important cost effective applications is the adoption of Rat-trap bond wall. Rat-trap bond is a special type of masonry construction which is economical when compared to conventional masonry. It consists of construction of headers and stretchers where bricks are used to lay vertically in the edge of the masonry wall, so as to form a cavity inside the wall as in Fig. 1. The Rat-trap bond is also thermally efficient and intuitively appears to be stronger, since the number of bed joints in a wall is lesser that that of the wall constructed with other bonds (Anon., 2011). Experimental investigation on Rat-trap bond masonry was carried out as described below.

\subsection{Test on Rat-trap bond prism}

First, prisms consisting of rat trap bond were tested under compression load in Figs. 3. The results of test on rat trap bond prisms are given in Tables 1 and 2.

\subsection{Development of Shock Table}

A simple version of the shaking table is a shock table, which is a horizontal table over which building models can be built and tested under base shock excitation. The shock table can be used to simulate the cumulative effects of ground motion by subjecting it to a series of base impacts. Using a simple pendulum impact device it is possible to control the magnitude of base shock. This helps in reproducing the masonry building failure modes. Also, after each shock it is possible to study the progress of failure of walls. Figure 4 shows the details of shock table. The main components of the shock table are the channel frame that supports the building model and the wheels that allow for motion. As for the wheels, a grooved pulley is used so that it allows for motion only in one direction as it rolls over the rails. Inverted ' $\mathrm{T}$ ' sections of size $50 \mathrm{~mm} \times 50 \mathrm{~mm} \times 6 \mathrm{~mm}$ are used as rails. The rails are supported over a masonry wall of $23 \mathrm{~cm}$ thickness and $45 \mathrm{~cm}$ high. An angle section of $40 \mathrm{~mm} \times 40 \mathrm{~mm} \times 6 \mathrm{~mm}$ is used for stiffness 
as shown in Fig. 4. An angle section of ISA $100 \times 100 \times 8$ is used to support the table frame as shown in DETAIL-X in Fig. 2. The total mass of the shock table with wheels is $200 \mathrm{~kg}$. The shock table is fabricated such that the motion is perpendicular to the plane of the cross walls (longer walls), thus causing out-of-plane vibrations in them. The photographic view of shock table is shown in Fig.4 (Saileysh Sivaraja, 2005).

\subsection{Preparation of Scaled Bricks}

The size of the scaled brick is $92 \mathrm{~mm} \times 43 \mathrm{~mm} \times 30 \mathrm{~mm}$. The thickness of masonry wall is $92 \mathrm{~mm}$. These bricks are prepared from bricks of size $175 \mathrm{~mm} \times 92 \mathrm{~mm} \times 30 \mathrm{~mm}$ by proper cutting using special tools. It avoids the usage of moulds for making scaled bricks

\subsection{Strength of Scaled Masonry}

The orthotropic strength of scaled masonry was obtained by testing the prisms. The mortar used was 1(cement): 10(lime): 20(sand). The strength of masonry used for the model is shown in Table 3.

\subsection{Construction of Scaled Building Models}

Openings were provided only in cross walls. No openings were provided in shear wall. This paper deals only with the study of out of plane (flexural) failure of the longer cross walls (Balasubramanian et al., ). It was decided to use a mortar which has low flexural strength 1 (cement): 10 (lime): 20 (sand) in order to limit the lateral load required to cause the flexural cracks in the model. First, two courses of the model was constructed using rich C.M mix (1:2) to avoid base shear cracks. Slab is $35 \mathrm{~mm}$ and its size is $2.10 \mathrm{~m} \times 1.10 \mathrm{~m}$. A $3 \mathrm{~mm}$ MS welded mesh with spacing 50 $\mathrm{mm}$ center to center was used as reinforcement for slab. Lintel band is $50 \mathrm{~mm}$ thickness with 4 nos. of $3 \mathrm{~mm}$ MS rod as main reinforcement and $2 \mathrm{~mm}$ MS wire at $50 \mathrm{~mm}$ center to center as stirrups. Table 4 shows the details of opening and structural features of-models.

\subsection{Base Impact Test}

The instrumentation required and the test setup is clearly shown in Fig.5 The base impact is very much useful to simulate the effects of lateral ground motions on building. In this experiment, pendulum impact device is used for base shock. The input energy is controlled by varying the height of release (h). The pendulum weight of $150 \mathrm{~kg}$ and $115 \mathrm{~kg}$ are used for model with and without roof slab, respectively. The chord length of release of pendulum is varied from $30 \mathrm{~cm}$ to $75 \mathrm{~cm}$. The weight of hammer is calculated as $10 \%$ of the total weight of shock table and masonry model.

\section{DISCUSSION OF TEST RESULTS}

The compressive strength of rat-trap bond prism of C.M. 1:5 is $0.87 \mathrm{MPa}$ and that of CM 1:4 is 1.30 MPa. This shows that bricks set-in a richer mortar is stronger than that in leaner mortar. The former is almost 49 per cent stronger than the latter. The amount of energy imparted during each shock has been calculated by knowing the velocity of impact and mass of the pendulum i.e. $1 / 2 \mathrm{mv}^{2}$ where $\mathrm{v}=\sqrt{ }(2 \mathrm{gh})$. Table 5 and 6 show the details of Base Impact Test conducted on models with and without roof slab respectively. The remarks columns in the tables describe the progress of collapse and failure modes in detail sequentially. Figures 6 and 7 show the vibration records of base impact for models with and without roof slab. Fig.8 show the failure patterns of both models (with and without roof slab), respectively.

From Tables and Figs., it can be observed that the damages in the case of model without roof slab are more severe and extensive than that with roof slab. The reason is that all four walls in the model without roof slab are not connected monolithically by a band in the form of roof slab. Each one had acted independently. There has been no separation of wall from the lintel in the case of model with roof slab. After 20 impact bricks have fallen out in the case of model without roof slab whereas it can be observed that the integrity of the wall has been maintained in the case of model with roof slab. 
The model without roof slab is less stiff than that with roof slab. This is evident by a comparison of values presented in Tables 5 and 6 . For the same velocity in the first impact, the energy capacity in the case of the model with roof slab is 30.66 per cent more than that of the model without roof slab. For various impacts the energy capacity of model without roof slab ranges from $44.45 \mathrm{Nm}$ to $3581.56 \mathrm{Nm}$. In contrast, the corresponding values for the model with roof slab are $58.08 \mathrm{Nm}$ to $4069.09 \mathrm{Nm}$. This shows that the sustainability of model with roof slab under base shock excitation is better than that without roof slab. The energy capacity in the case of model with slab is 33.8 per cent after 21 impacts is greater than that of the model without slab.

Table 1 Compressive Strength on Rat-trap bond prism of CM 1:5

\begin{tabular}{|c|c|c|c|c|c|c|}
\hline $\begin{array}{c}\text { Sl. } \\
\text { No. }\end{array}$ & $\begin{array}{c}\text { Size of } \\
\text { Prism }\end{array}$ & $\begin{array}{c}\text { Mortar } \\
\text { Proportion }\end{array}$ & $\begin{array}{c}\text { Ultimate } \\
\text { Load } \\
(\mathbf{N})\end{array}$ & $\begin{array}{c}\text { Cross } \\
\text { section area } \\
\left(\mathbf{m m}^{2}\right)\end{array}$ & $\begin{array}{c}\text { Compressive } \\
\text { strength } \\
\left(\mathbf{N} / \mathbf{m m}^{2}\right)\end{array}$ & $\begin{array}{c}\text { Average } \\
\text { Compressive } \\
\text { Strength } \\
\left(\mathbf{N} / \mathbf{m m}^{\mathbf{2}}\right)\end{array}$ \\
\hline 1. & $900 \times 400 \times 220$ & $1: 5$ & $7.5 \times 10^{4}$ & $400 \times 220$ & 0.85 & \multirow{2}{*}{0.87} \\
\cline { 1 - 5 } 2. & $900 \times 400 \times 220$ & $1: 5$ & $7.2 \times 10^{4}$ & $400 \times 220$ & 0.82 & \\
\hline 3. & $900 \times 400 \times 220$ & $1: 5$ & $8.4 \times 10^{4}$ & $400 \times 220$ & 0.95 & \\
\hline
\end{tabular}

Table 2 Compressive Strength on Rat trap bond prism of CM 1:4

\begin{tabular}{|c|c|c|c|c|c|c|}
\hline $\begin{array}{c}\text { Sl. } \\
\text { No. }\end{array}$ & $\begin{array}{c}\text { Size of } \\
\text { Prism }\end{array}$ & $\begin{array}{c}\text { Mortar } \\
\text { Proportion }\end{array}$ & $\begin{array}{c}\text { Ultimate } \\
\text { Load } \\
(\mathbf{N})\end{array}$ & $\begin{array}{c}\text { Cross } \\
\text { section area } \\
\left(\mathbf{m m}^{2}\right)\end{array}$ & $\begin{array}{c}\text { Compressive } \\
\text { strength } \\
\left(\mathbf{N} / \mathbf{m m}^{2}\right)\end{array}$ & $\begin{array}{c}\text { Average Compressive } \\
\text { Strength } \\
\left(\mathbf{N} / \mathbf{m m}^{2}\right)\end{array}$ \\
\hline 1. & $900 \times 400 \times 220$ & $1: 4$ & $9.6 \times 10^{4}$ & $400 \times 220$ & 1.09 & \multirow{2}{*}{1.30} \\
\cline { 1 - 5 } 2. & $900 \times 400 \times 220$ & $1: 4$ & $10.8 \times 10^{4}$ & $400 \times 220$ & 1.23 & \\
\hline 3. & $900 \times 400 \times 220$ & $1: 4$ & $13.8 \times 10^{4}$ & $400 \times 220$ & 1.57 & \\
\hline
\end{tabular}

Table 3. Strength of Scaled Masonry

\begin{tabular}{|l|l|c|}
\hline 1. & Compressive strength (normal to joints) & $1.183 \mathrm{MPa}$ \\
\hline 2. & Flexural strength (normal to joints) & $0.382 \mathrm{MPa}$ \\
\hline 3. & Flexural strength (Parallel to joints) & $0.462 \mathrm{MPa}$ \\
\hline 4. & Shear strength & $0.041 \mathrm{MPa}$ \\
\hline
\end{tabular}

Table 4 Details of Rat-trap Bond Models

\begin{tabular}{|c|c|c|}
\hline Model & Details of opening & Structural Features \\
\hline $\begin{array}{l}\text { Model without roof } \\
\text { slab. }\end{array}$ & $\begin{array}{l}\text { One door and one window on the east wall } \\
\text { and two windows on the west wall; } \\
\text { Windows } 0.30 \mathrm{~m} \times 0.45 \mathrm{~m} \text { and } 0.45 \times .0 .45 \\
\text { Doors } 0.30 \mathrm{~m} \times 0.70 \mathrm{~m} \text {. Shear wall has no } \\
\text { openings }\end{array}$ & $\begin{array}{l}\text { Size } 2 \mathrm{~m} \times 1 \mathrm{~m} \times 1 \mathrm{~m} \\
\text { Mortar: cement-lime mortar }(1: 10: 20)\end{array}$ \\
\hline Model with roof slab. & $\begin{array}{l}\text { One door and one window on the east wall } \\
\text { and two windows on the west wall } \\
\text { Windows } 0.30 \mathrm{~m} \times 0.45 \mathrm{~m} \text { and } 0.45 \times 0.45 \\
\text { Door } 0.30 \mathrm{~m} \times 0.70 \mathrm{~m} \text { Shear wall has no } \\
\text { openings }\end{array}$ & $\begin{array}{l}\text { Size } 2 \mathrm{~m} \times 1 \mathrm{~m} \times 1 \mathrm{~m} \\
\text { Thickness of roof slab is } 35 \mathrm{~mm} .3 \mathrm{~mm} \text { MS } \\
\text { weld mesh spacing } 50 \mathrm{~mm} \text { center to center is } \\
\text { used as slab reinforcement Mortar: cement- } \\
\text { lime mortar }(1: 10: 20)\end{array}$ \\
\hline
\end{tabular}


Table 5 Details of base impact test conducted on rat-trap bond masonry model with roof slab

\begin{tabular}{|c|c|c|c|c|l|}
\hline $\begin{array}{c}\text { Impact } \\
\text { No. }\end{array}$ & $\begin{array}{c}\text { Velocity } \\
\text { of Impact } \\
(\mathbf{m} / \mathbf{s})\end{array}$ & $\begin{array}{c}\text { Cumulative } \\
\text { Energy } \\
(\mathbf{N m})\end{array}$ & $\begin{array}{c}\text { PBA } \\
\left(\mathbf{m} / \mathbf{S e c}^{2}\right)\end{array}$ & $\begin{array}{c}\text { PRM } \\
\left(\mathbf{m} / \mathbf{S e c}^{2}\right)\end{array}$ & \multicolumn{1}{|c|}{ Remarks } \\
\hline 1. & 0.88 & 58.08 & 10.69 & 10.40 & $\begin{array}{l}\text { Pendulum released from 30cm. } \\
\text { Pendulum is 150kg. No visible cracks. }\end{array}$ \\
\hline 4. & 1.33 & 248.83 & 7.75 & 42.28 & $\begin{array}{l}\text { Pendulum released from 45cm. Horizontal crack } \\
\text { developed below lintel level. }\end{array}$ \\
\hline 5. & 1.33 & 514.17 & 9.12 & 49.5 & $\begin{array}{l}\text { Horizontal and diagonal cracks are visible at east } \\
\text { and south wall. }\end{array}$ \\
\hline 8. & 1.77 & 1014.48 & 13.05 & 27.27 & $\begin{array}{l}\text { Pendulum released from 60cm. Cracks below sill } \\
\text { level in west wall. }\end{array}$ \\
\hline 10. & 1.77 & 1484.42 & 9.91 & 17.76 & $\begin{array}{l}\text { Horizontal and diagonal cracks below lintel level } \\
\text { in west wall }\end{array}$ \\
\hline
\end{tabular}

PBA : Peak Base Acceleration

PRM : Peak Response (Acceleration) of Model

Table 6 Details of base impact test conducted on rat-trap bond masonry model without roof slab

\begin{tabular}{|c|c|c|c|c|c|}
\hline $\begin{array}{l}\text { Impact } \\
\text { No. }\end{array}$ & $\begin{array}{l}\text { Velocity } \\
\text { of Impact } \\
(\mathrm{m} / \mathrm{s})\end{array}$ & $\begin{array}{l}\text { Cumulative } \\
\text { Energy } \\
(\mathrm{Nm})\end{array}$ & $\begin{array}{c}\text { PBA } \\
\left(\mathbf{m} / \mathbf{S}^{2}\right)\end{array}$ & $\begin{array}{r}\text { PRM } \\
\left(\mathrm{m} / \mathbf{S}^{2}\right)\end{array}$ & Remarks \\
\hline 1. & 0.88 & 44.45 & 12.85 & 26.0 & $\begin{array}{l}\text { Pendulum released from } 30 \mathrm{~cm} \text {. Mass of Pendulum } \\
\text { is } 115 \mathrm{~kg}\end{array}$ \\
\hline 3. & 1.33 & 190.71 & - & 25.57 & $\begin{array}{l}\text { Pendulum released from } 45 \mathrm{~cm} \text {. First crack below } \\
\text { lintel level in east wall. }\end{array}$ \\
\hline 4. & 1.33 & 294.48 & 15.50 & 49.05 & $\begin{array}{l}\text { Diagonal crack below lintel in south shear wall. } \\
\text { Crack developed at door open in East wall and } \\
\text { continued up to south west corner. }\end{array}$ \\
\hline 15. & 1.77 & 1960.30 & 5.30 & 40.32 & $\begin{array}{l}\text { More inward displacement of wall in between door } \\
\text { and window in eastern side. }\end{array}$ \\
\hline 16. & 1.77 & 2140.44 & 4.71 & 28.84 & $\begin{array}{l}\text { Brick pieces fallen at sill level of right end window } \\
\text { of west wall. }\end{array}$ \\
\hline 17. & 1.77 & 2320.58 & 5.30 & 33.75 & $\begin{array}{l}\text { Outward displacement of wall between windows and } \\
\text { south east corner highly damaged. }\end{array}$ \\
\hline 19. & 1.77 & 2680.86 & 5.10 & 30.62 & $\begin{array}{l}\text { More outward displacement of wall between } \\
\text { windows in western side. }\end{array}$ \\
\hline 20. & 1.77 & 2861.00 & 5.60 & 31.28 & Severe damage in North side wall. \\
\hline 21. & 1.77 & 3041.14 & 4.71 & 32.57 & $\begin{array}{l}\text { Portion of wall between windows likely to fall in } \\
\text { western side. }\end{array}$ \\
\hline 23. & 1.77 & 3401.42 & 3.04 & 44.73 & $\begin{array}{l}\text { Portion of wall between windows fallen in western } \\
\text { side }\end{array}$ \\
\hline 24. & 1.77 & 3581.56 & 4.91 & 12.56 & $\begin{array}{l}\text { Wall became non functional below lintel in all sides } \\
\text { but portion above lintel is intact. }\end{array}$ \\
\hline
\end{tabular}

PBA : Peak Base Acceleration

PRM : Peak Response (Acceleration) of Model 


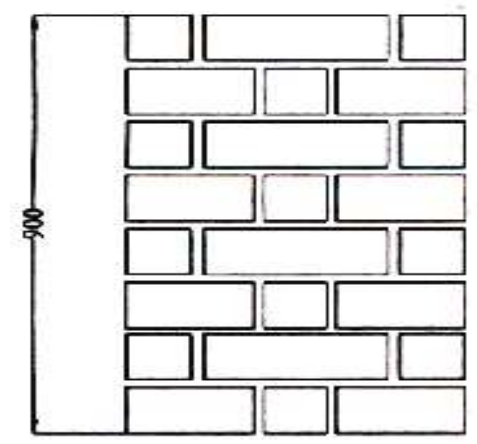

Eleevation

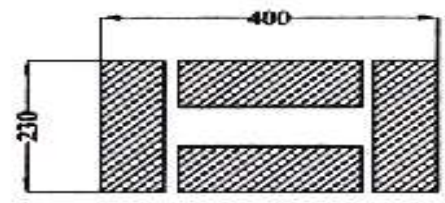

Section of Even layer

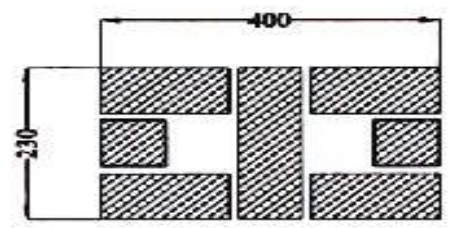

Section of Odd layer

Fig. 1 Rat trap bond prism

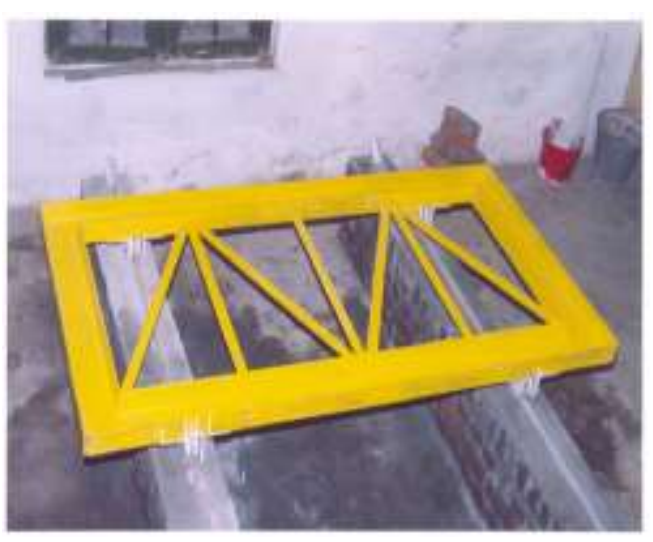

Fig.4 Plan view of shock table

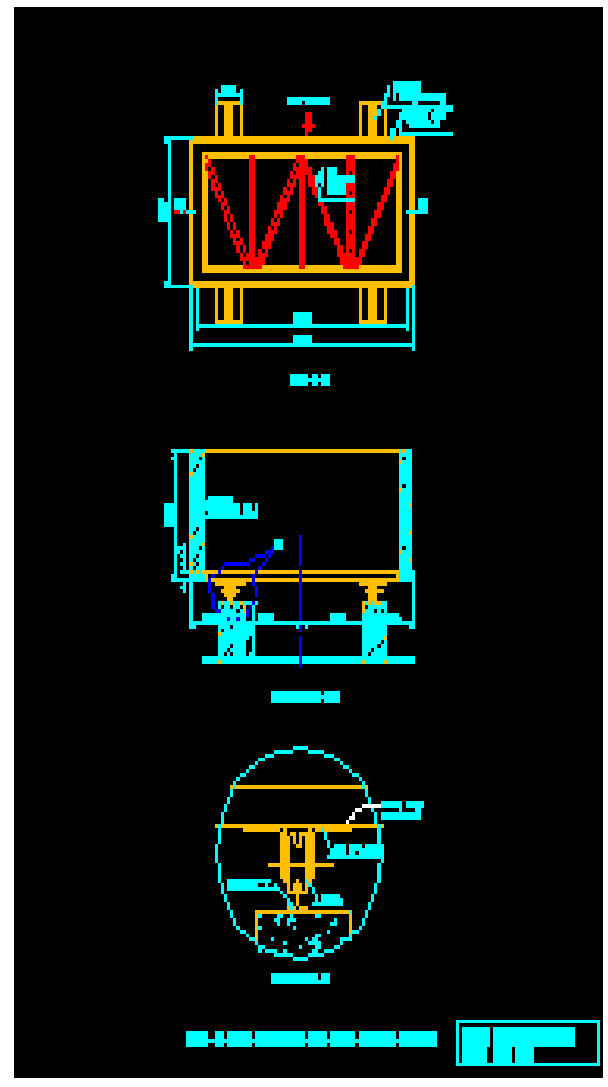

Fig. 2 Details of shock table

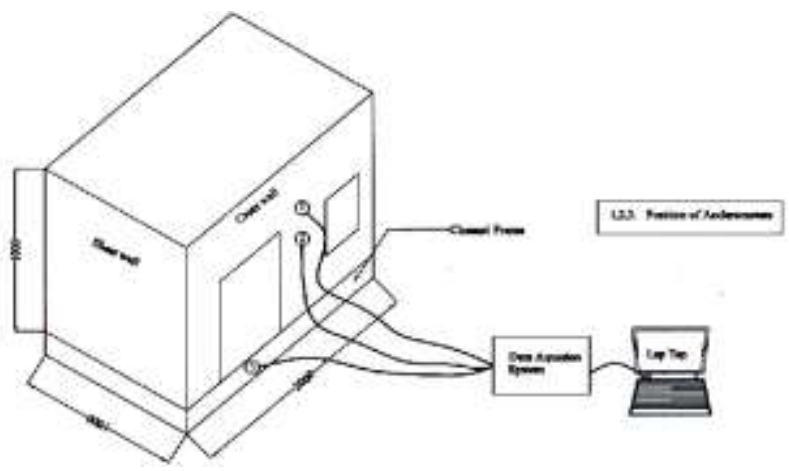

Fig.5 Schematic diagram of vibration measurement 


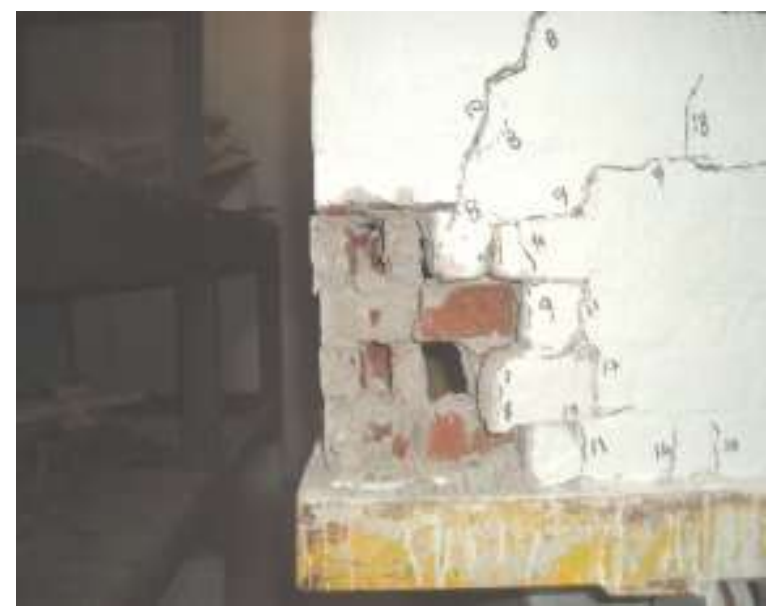

Fig.6 Model with slab after $17^{\text {th }}$ impact

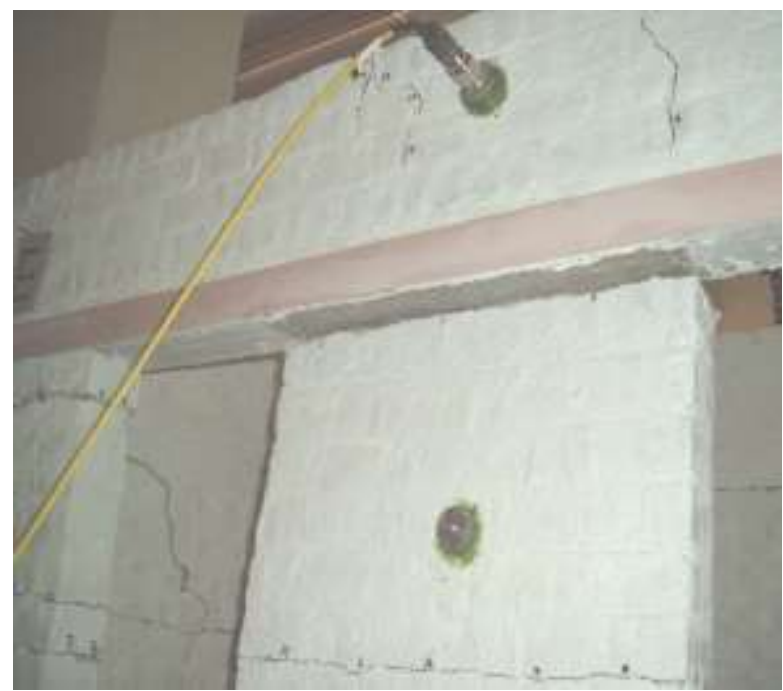

Fig.8 Model without slab after 13th impact

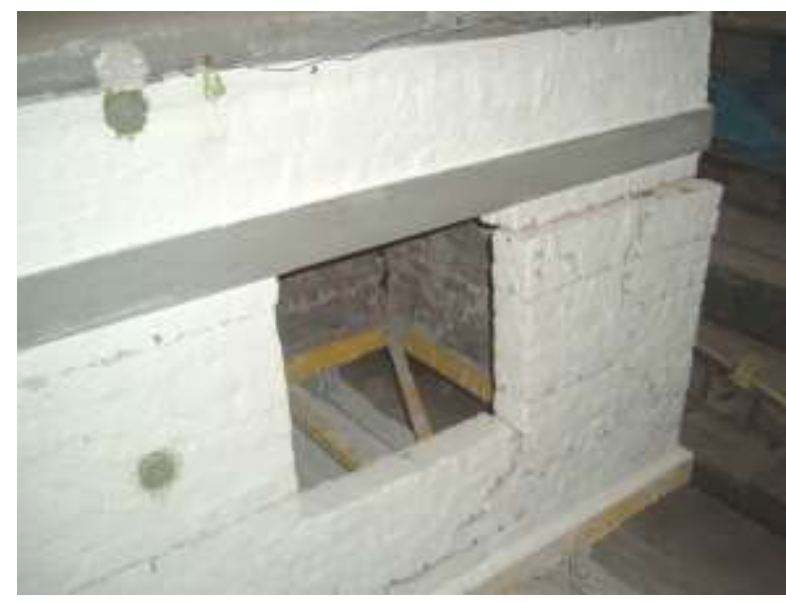

Fig.7 Model with slab after $19^{\text {th }}$ impact

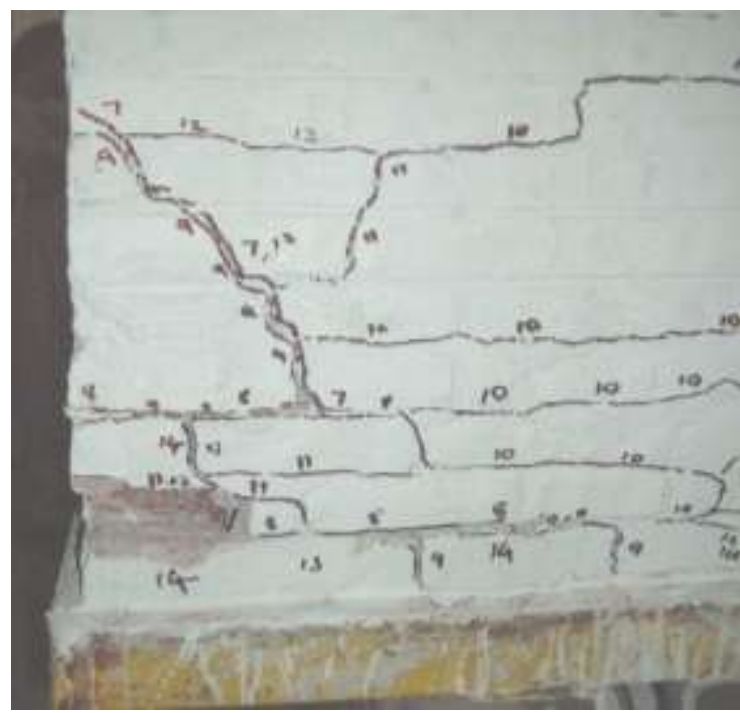

Fig.9 Model without slab after $14^{\text {th }}$ impact

\section{CONCLUSIONS}

In this investigation an attempt has been made to simulate the out-of-plane failure of box-type rat-trap bond masonry building as those observed in the event of a strong earthquake. Shock Table tests of (1/3) scale rat-trap bond masonry building models were carried out to simulate such failure. It can be seen that the total energy imparted to the model without roof slab is $3581.56 \mathrm{Nm}$ before its total collapse. The model with roof slab was capable of withstanding a total energy of $4069.09 \mathrm{Nm}$ before its total collapse. Thus the energy capacity of model with roof slab is greater than that of the model without roof slab. It was observed in this experimental investigation that the damages in the case of model without roof slab are more severe and extensive than that with roof slab. The onset of damage is much earlier in the case of model without slab than that with slab. The integrity of walls was ensured by the provision of the roof slab. This shows that the sustainability of model with roof slab under base shock excitation is better than that without roof slab. This reveals that design of roof plays an important role in design of masonry system subjected to base shock excitation. 


\section{References}

[1] Anon., (2011), "Validation of Rat-trap Bond Wall and Filler Block Floors," Seminar Notes, January 30, Building Technology Centre, Anna University, Chennai, pp. 175 - 197.

[2] Balasubramanian R., Saileysh Sivaraja S., Senthil R. and Santhakumar A.R. (2005). 'Behaviour of Masonry Building under base shock vibrations', National Symposium on Structural Dynamics, Random Vibrations and Earthquake Engineering, IISc., Bangalore, India, pp. 99-106.

[3] Borri, A., Corradi, M., Vignoli, A., (2001), "Seismic Upgrading of Masonry Structures with FRP," Proceedings of the $7^{\text {th }}$ International Conference on Inspection, Appraisal, Repairs and Maintenance of Buildings and Structures, Nottingham Trent University, Nottingham, September 11 -1 3, pp. 43-54.

[4] Deodhar, S.V and Patel, A.N., (2010), "Behaviour of Brick Masonry in Compression", Journal of Structural Engineering, Vol. 22, No. 4, pp. 221-224.

[5] EBC code , "Improving Earthquake Resistance of Low Strength Masonry Buildings - Guidelines,"

[6] Jagdish K.S., Ragunath S. and Nanjunda Rao K.S. (2002), 'Shock Table Studies on Masonry Building Model with Containment Reinforcement', Journal of Structural Engineering, Vol. 29, No.1, pp. 9-17.

[7] Patil, K.A. and Achawal, V.G., (2000), "Strength of Brick Masonry Prisms Using Low Strength Bricks and Cement Mortar", Proceedings of 6th Inter-national Seminar on Structural Masonry for Developing Countries, Organised by the Department of Civil Engineering, I.I.Sc., Bangalore, 11-13 October, pp. 134-137.

[8] Shrive, N.G., (2004), "Use of Fibre Reinforced Polymers to Improve Seismic Resistance of Masonry," SISMICA $2004-6^{\text {th }}$ Congresso Nacional de Sismologia e Engenharia Sismica, Alberta, Canada, pp. 197-208.

[9] S.Saileysh Sivaraja,(2005), "Behaviour of Rat-trap Bond Masonry Building Under Base Shock Vibration" M.S. Dissertation, Anna University, Chennai, 2005, 54 pp.

[10] Thomas, K., (1971), "Structural Brickwork - Materials and Performance," The Structural Engineer, Vol. 49, No. 10 , pp. $441-450$. 